\title{
Humus is Life of Soil by Allah Dad Khan
}

\author{
Allah Dad Khan* \\ University of Agriculture Peshawar, Pakistan
}

Submission: July 06, 2016; Published: July 31, 2017

"Corresponding author: Allah Dad Khan, University of Agriculture Peshawar, Pakistan, Email: allahdad52@gmail.com

\section{Opinion}

Humus" (Origin: 1790-1800; < Latin: earth, ground is degraded organic material in soil, which causes some soil layers to be dark brown or black.

In soil science, humus refers to any organic matter that has reached a point of stability, where it will break down no further and might, if conditions do not change, remain essentially as it is for centuries, if not millennia.

In agriculture, humus is sometimes also used to describe mature compost, or natural compost extracted from a forest or other spontaneous source for use to amend soil. It is also used to describe a topsoil horizon that contains organic matter (humus type, humus form, humus profile, humus, organic matter that has decayed to a relatively stable, amorphous state. It is an important biological constituent of fertile soil . Humus is formed by the decomposing action of soil microorganisms (e.g., bacteria and fungi), which break down animal and vegetable material into elements that can be used by growing plants. Technically, humus, as the end result of this process, is less valuable for plant growth than are the products formed during active decomposition (see fertilizer). Because of its low specific weight and high surface area, humus has a profound effect upon the physical properties of mineral soils with regard to improved soil structure, water intake and reservoir capacity, ability to resist erosion, and the ability to hold chemical elements in a form readily accessible to plants.

Humus has a characteristic black or dark brown color, due to an accumulation of organic carbon (Figure 1).

A. The mineralization process that converts raw organic matter to the relatively stable substance that is humus feeds the soil population of micro-organisms and other creatures, thus maintaining high and healthy levels of soil life.

B. The rate at which raw organic matter is converted into humus promotes (when fast) or limits (when slow) the coexistence of plants, animals and microbes in terrestrial ecosystems.

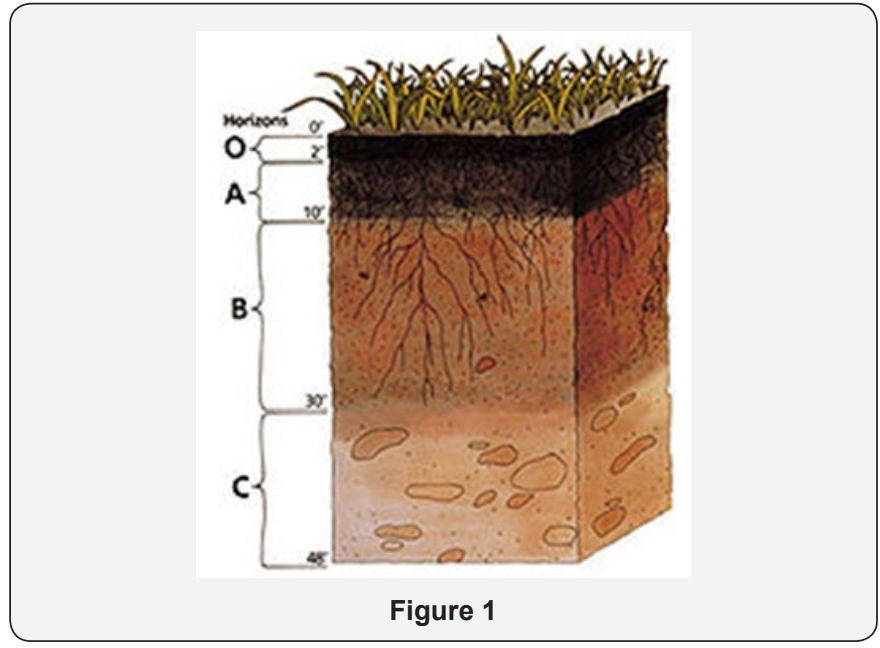

C. Effective and stable humus (see below) are further sources of nutrients to microbes, the former providing a readily available supply while the latter acts as a more long-term storage reservoir.

D. Decomposition of dead plant material causes complex organic compounds to be slowly oxidized (lignin-like humus) or to break down into simpler forms (sugars and aminosugars, aliphatic and phenolic organic acids) which are further transformed into microbial biomass (microbial humus) or are reorganized (and still oxidized) in humic assemblages (fulvic and humic acids, humins) which bind to clay minerals and metal hydroxides. There has been a long debate about the ability of plants to uptake humic substances from their root systems and to metabolize them. There is now a consensus about humus as playing a hormonal role rather than a nutritional role in plant physiology.

E. Humus is a colloidal substance, and increases the soil's cation exchange capacity, hence its ability to store nutrients by chelation as can clay particles; thus while these nutrient cations are accessible to plants, they are held in the soil safe from leaching away by rain or irrigation. 
F. Humus can hold the equivalent of $80-90 \%$ of its weight in moisture, and therefore increases the soil's capacity to withstand drought conditions.

G. The biochemical structure of humus enables it to moderate- or buffer- excessive acid or alkaline soil conditions.

H. During the humification process, microbes (bacteria and fungi) secrete sticky gums and mucilages; these contribute to the crumb structure of the soil by holding particles together, allowing greater aeration of the soil. Toxic substances such as heavy metals, as well as excess nutrients, can be chelated (that is, bound to the complex organic molecules of humus) and prevented from entering the wider ecosystem, thereby detoxifying it.

I. The dark color of humus (usually black or dark brown) helps to warm up cold soils in the spring.

Soils contain a great amount of matter which results from the decay of vegetables and animals; to a compound of which with earthy material the name of humus is given. This was once incorrectly supposed to give the whole nutriment of the plant. Trees and plants, instead of abstracting carbon from the earth, really, by taking it from the air, and subsequently dying and decaying, annually by their leaves, and finally altogether, give carbon and other atmospheric elements to the soil. As above said, all plants by their leaves absorb carbonic acid from the air, and retain carbon, giving out oxygen. It is evident, therefore, that the leaves are of great importance to the plant. So are the roots, for their absorbing office. Thus it is true that the growth of a plant is always proportioned to the surface of its roots and leaves together. Vegetation, in its simplest form, consists in the abstraction of carbon from carbonic acid, and hydrogen from water; but the taking of nitrogen also, from ammonia especially, is important to them, and most of all, to those which are most nutritious, as the wheat, rye, barley, \&c., whose seeds contain gluten and other nitrogenous principles of the greatest value for food. Plants will grow well in pure charcoal, if supplied with rainwater, for rain-water contains ammonia.
Animal substances, as they putrefy, always evolve ammonia, which plants need and absorb. Thus is explained one of the benefits of manuring, but not the only one as we shall see presently. Animal manure, however, acts chiefly by the formation of ammonia. The quantity of gluten in wheat, rye, and barley is very different; and they contain nitrogen in varying proportions. Even in samples of the same seed the quantity varies, and why? Evidently because one variety has been better fed with its own appropriate fertilizer than another which has been reared on a soil less accurately adapted by artificial means for its growth. French wheat contains 12 per cent. of gluten; Bavarian 24 per cent. Sir H. Davy obtained 19 per cent. from winter, and 24 from summer wheat; from Sicilian 21, from Barbary wheat 19 per cent. Such great differences must be owing to some cause, and this we find in the different methods of cultivation.

An increase of animal manure gives rise not only to an increase in the number of seeds, but also to a remarkable difference in the proportion of gluten which those seeds contain. Among manures of animal origin there is great diversity. Cow dung contains but a small proportion of nitrogen. One hundred parts of wheat, grown on a soil to which this material was applied, afforded only 11 parts of gluten and 64 of starch; while the same quantity of wheat, grown on a soil fertilized with human urine, yielded 35 per cent. of gluten, and of course a smaller proportion of less valuable ingredients. During the putrefaction of urine, ammoniacal salts are formed in large quantity, it may be said, exclusively; for under the influence of warmth and moisture, the most prominent ingredient of urine is converted into carbonate of ammonia.

\section{How does humus effect soil?}

Because of its low specific weight and high surface area, humus has a profound effect upon the physical properties of mineral soils with regard to improved soil structure, water intake and reservoir capacity, ability to resist erosion, and the ability to hold chemical elements in a form readily accessible to plants.

\section{Your next submission with Juniper Publishers will reach you the below assets}

- Quality Editorial service

- Swift Peer Review

- Reprints availability

- E-prints Service

- Manuscript Podcast for convenient understanding

- Global attainment for your research

- Manuscript accessibility in different formats

( Pdf, E-pub, Full Text, Audio)

- Unceasing customer service

Track the below URL for one-step submission https://juniperpublishers.com/online-submission.php 